21. Looschelders, D., Schuldrecht AT, 9. Aufl., Verlag Franz Vahlen, München 2011 (in German)

22. Bundesverfassungsgericht - BVerfG, NJW 1998, 3557 (in German)

23. Simejnij kodeks Ukrayini vid 10.02.2002 №2947-III. Vidomosti Verhovnoyi Radi Ukrayini. 2002. № 21-22. st.135 (iz ostannimi zminami vid 30.03.2020) (in Ukrainian)

24. Romovska Z.V. Simejnij kodeks Ukrayini. Naukovo-praktichnij komentar [Family Code of Ukraine. Scientific and practical commentary]. Kiyiv: In Yure, 2003. $532 \mathrm{~s}$ (in Ukrainian)
25. Lorenz, A., Das Selbstbestimmungsrecht des einsichtsfähigen Minderiährigen bei Eingriffen in die körperliche Integrität, NZFam 2017, S. 782-788 (in German)

26. Stern, K., Das Staatsrecht der Bundesrepublik Deutschland, Verlag C.H. Beck 1988, Bd. III/1, § 70 V 2d (in German)

Received: $15 / 09 / 2020$ Accepted: $30 / 10 / 2020$

K. Kravchenko, lawyer of the first rank,

B. Schloer, Dr of Law (German), Associate Prof.

Taras Shevchenko National University of Kyiv, Kyiv, Ukraine

\title{
MINORS AS SUBJECTS OF LAW: \\ COMPARISON OF THE LEGAL REGULATION IN GERMANY AND UKRAINE
}

This article deals with the legal regulation of minors in Germany and Ukraine. Minors do not have enough intellectual ability to predict legal consequences of their acts. That is why they need a special protection. The study primarily focuses on minors as a subject of law in Civil and Family Law. The aim of the article is to study and compare legal regulation for minors under both German and Ukrainian law.

First of all, the notion of minors is analysed. It is assumed that the term minor is not clear. It has different meanings in both German and Ukrainian national law. International legislation does not clear the issue.

Second, the legal regulation of minors is studied. The issue of age limits in the national Civil Law of Germany as well as Ukraine are examined and compared. It is suggested that the age limits are closely connected to the legal capacity of the natural persons. The comparative analysis of legal regulation of minors in Civil Law of both countries shows that the provisions of German Civil Law concerning the legal capacity of minors differ sufficiently from Ukrainian ones. For example, in Germany children under seven years old do not have legal capacity, while minors at the age from seven to eighteen years old have limited legal capacity. Whereas in Ukraine, minors under fourteen years old have partial legal capacity, while minors between fourteen and eighteen years old have incomplete legal capacity.

Last but not least, the minors' rights and their scope from the point of view of a family and the state are explored. The comparison shows that the legal regulation of minors' rights as well as an attitude to the minors in society in Germany differs from Ukraine. Finally, it is proposed to ameno the Family Code of Ukraine in respect of minors' rights. It is wise to consider an opinion of minors in family issues.

Keywords: minors, rights of minors, legal capacity of minors, age limit in civil law.

Bulletin of Taras Shevchenko National University of Kyiv. Legal Studies, 2020; 3 (114): 30-35

УДК: 342.7:341.231.14

DOI: https:doi.org/10.17721/1728-2195/2020/5.115-7
ISSN 1728-2195

(C) Taras Shevchenko National University of Kyiv, Publishing center "Kyiv University", 2020

А. Крижевський, канд. іст. наук, асист. ORCID ID: 0000-0002-7234-7500,

O. Крижевська, канд. юрид. наук, асист. ORCID ID: 0000-0003-4989-6322

Київський національний університет імені Тараса Шевченка, Київ, Україна

\section{ДЕРЖАВНА ПОЛІТИКА У СФЕРІ ОХОРОНИ ЗДОРОВ'Я У ПРОВІДНИХ КРАЇНАХ ЄВРОПИ: ПРАВОВИЙ АСПЕКТ}

Досліджено державну політику у сфері охорони здоров'я у провідних країнах Європи: Швеції, ФРН і Франції. Метою цієї статті є аналіз і систематизація основних організаційно-правових засад державної політики у сфері охорони здоров'я у країнах ЄС і розроблення рекомендацій щодо вдосконалення та реформування української системи охорони здоров'я. Дослідження здійснювали з погляду принципів історизму, об'єктивності, різнобічності, взаємодоповнюваності й обгрунтованості, що створило надійну методологічну основу для комплексного аналізу предмета дослідження. У роботі застосовували порівняльно-правовий метод, формально-юридичний, системно-структурний, метод класифікації, метод моделювання, конкретно-статистичний, історико-правовий та інші методи наукового аналізу відповідно до предмета дослідження. У статmі стверджується, що державна політика у сфері охорони здоров'я унікальна в кожній країні, а на ї̈ формування вплинули історичне минуле, політичний режим, національний менталітет та інші фактори. Зазначено необхідність створення в Україні в ході реформи системи охорони здоров'я спеціального Кодексу законів у цій галузі, який сприятиме якісному правовому регулюванню відносин між пацієнтами, закладами охорони здоров'я, страховими компаніями та державою. Автори вважають, що одним із подальших напрямів реформування системи охорони здоров'я України перш за все має стати запровадження обов'язкового державного медичного страхування. Обгрунтовано, що страхування повинно здійснюватися на тристоронній основі: відрахування від доходів підприємиів, відрахування з державного бюджету та страхові внески населення. Доведено необхідність посилення заходів, спрямованих на попередження та профілактику виникнення захворюваності.

Ключові слова: охорона здоров'я, державна політика, нормативно-правове забезпечення, медичне страхування, іноземний досвід, реформа, кодекс, страхові внески.

ВСтУП. Конституцією України кожному громадянину гарантовано право на безкоштовну охорону його здоров'я, на одержання медичної допомоги і медичного страхування. Тому для будь-якої держави стабільність системи охорони здоров'я та її ефективність $€$ одним із головних завдань. Державна політика в сфері охорони здоров'я полягає у забезпеченні діяльності та розвитку системи охорони здоров'я шляхом видачі необхідних нормативно-правових актів, фоормуванні пріоритетів, доктрин, концепцій і сприянні реалізації програм, спрямованих на зміцнення здоров'я населення. Вивчення досвіду формування та функціонування державної політики в ссрері охорони здоров'я у європейських країнах у межах пошуку шляхів удосконалення та реформування української політики в цій галузі визначає актуальність цього дослідження.

Історіографрія, дотична до об'єкта, предмета, хронології та географії цієї статті, має ряд здобутків і прогалин. Серед великої кількості робіт щодо поставленої проблеми можна виділити загальні дослідження В. Воробйова [1], В. Долота [2], Ю. Матвієнка [4; 5], М. Співак [9] та інших, які присвячені проблемам систем 
охорони здоров'я європейських країн. Також зазначимо роботи В. Москаленка [6], A. Anell, A. Glenngard, S. Merkur [10], P. Kaati [14] та інших, які стосуються систем охорони здоров'я конкретних країн. Незважаючи на достатню кількість наукових робіт із дотичних до поставленої проблеми тем, аналіз наукової літератури показав, що державна політика у сфері охорони здоров'я досліджена фрагментарно й не всі аспекти проблеми можна вважати остаточно дослідженими

Метою цієї статті $є$ аналіз і систематизація основних організаційно-правових засад державної політики у сфері охорони здоров'я у країнах ЄС і розроблення рекомендацій щодо вдосконалення та реформування української системи охорони здоров'я. Об'єктом дослідження $€$ державна політика забезпечення права на охорону здоров'я.

Методологія дослідження. Обґрунтованість теоретичних положень, висновків і достовірність результатів дослідження забезпечено використанням сукупності філософських, загальнонаукових і спеціальних наукових методів. Порівняльно-правовий і фрормально-юридичний методи стали основою для аналізу норм нормативно-правових актів у сфері охорони здоров'я. За допомогою системно-структурного методу досліджувалися компоненти державної політики в галузі охорони здоров'я та їхній взаємозв'язок одного 3 одним. У роботі також застосовували метод класифікації, метод моделювання, конкретно-статистичний, історико-правовий та інші методи наукового аналізу відповідно до предмета дослідження.

ВИКЛАД ОСНОВНОГО МАТЕРІАЛУ. ДержавнУ політику у сфері охорони здоров'я слід розглядати як систему заходів органів влади у здійсненні правового й організаційного регулювання у сфері надання медичної допомоги, збереження і зміцнення здоров'я населення. Ключовими елементами державної політики у сфері охорони здоров'я, на думку авторів, $€$ способи фінансування вказаної системи, організаційно-правові механізми управління цією системою та заходи, спрямовані на профілактику та запобігання захворюваності.

Сьогодні існує безліч класифікацій систем охорони здоров'я за способом фрінансування, однак їх можна звести до трьох класичних моделей: переважно державна або система Бевериджа (Великобританія, Швеція та ін.), переважно приватна (США, Японія, Південна Корея), і змішана або система Бісмарка (Німеччина, Франція та ін.). Детальніше розглянемо системи охорони здоров'я деяких провідних країн Європи. Відразу зазначимо, що в сучасному глобалізованому світі системи охорони здоров'я повною мірою не вкладаються в жодну із цих моделей, оскільки в ході ресоорм запозичуються ідеї й окремі елементи. Сучасні системи охорони здоров'я стали, по суті, настільки гібридними, що чітко віднести їх до конкретної групи дуже складно. Детально розглянемо державну політику у сфері охорони здоров'я декількох європейських країн, проаналізувавши систему профілактичних заходів, особливості фрінансування й управління.

Державна політика у сфері охорони здоров'я Швеції. Шведська система охорони здоров'я $є$ бюджетною (хоча деякі дослідники відносять її не до державної моделі (моделі Бевериджа), а виділяють в окрему скандинавську групу), децентралізованою системою лікувально-профілактичних закладів із надання медичної допомоги. Ця система побудована за адміністративнотериторіальним принципом і має три рівні управління (загальнодержавний (центральний), регіональний і місцевий). Однак, незважаючи на децентралізацію, система функціонує як добре злагоджений механізм. Загаль- нодержавні органи управління відповідають за розробку державної політики та правової бази у сфері охорони здоров'я й наділені наглядовими функціями. На регіональний рівень делеговано повноваження з планування та організації медичного обслуговування. Місцевим органам передано функції з організації роботи медикосоціальних служб, що забезпечують догляд за дітьми, людьми похилого віку, інвалідами, хворими з хронічними психічними розладами [8, с. 4-7].

Можна виокремити три джерела фрінансування: податки (центральні, регіональні та місцеві), державна система соціального страхування та власні кошти пацієнтів (платні медичні послуги та приватне медичне страхування). Медична допомога, яка надається всім постійним мешканцям регіону незалежно від громадянства, фрінансується переважно за рахунок регіональних податків, що становить близько $72 \%$ всіх витрат на охорону здоров'я. Прямі державні фрінансові вливання, загальні й цільові субсидії, становлять 13 \% витрат системи охорони здоров'я [14, с. 299]. Спеціалізоване лікування, дороге медичне обслуговування, стоматологічні послуги, оплата ліків покривають за рахунок системи державного соціального страхування, частка якого в системі фрінансування сфрери охорони здоров'я не перевищує $15 \%$. Система також передбачає виплату допомоги у зв'язку з хворобою, реабілітацією й на придбання допоміжних засобів, на консультації 3 планування сім'ї, транспортні витрати. На платні медичні послуги припадає приблизно 3 \% усіх видатків на охорону здоров'я $[10$, с. 14]. Добровільне медичне страхування у Швеції не отримало значного поширення. На охорону здоров'я у Швеції виділяють 9,5 \% ВВП [6].

Шведський уряд реалізує багато державних програм у сфрері охорони здоров'я. Так, 2016 р. ухвалено нову чотирирічну цілісну стратегію, направлену на зменшення вживання алкоголю, наркотиків, допінгу і тютюну [11]. Окремий вектор державної політики направлений на проблеми сексуального та репродуктивного здоров'я, забезпечення гендерної рівності. Задля цього урядом ухвалено спеціальну багаторічну (до 2030 р.) програму. Зазначимо, що реалізація заходів усіх державних програм покладається не лише на Міністерство охорони здоров'я і соціальної політики, а й на інші міністерства та муніципалітети. Особливо це стосується соціальної роботи з вразливим категоріями населення: неповнолітніми чи людьми з обмеженими можливостями [22].

Державна політика у сфері охорони здоров'я Нiмеччини. Організація і фрінансування системи охорони здоров'я в Німеччині базується на принципах соціальної солідарності, децентралізації та саморегуляції. Федеральне міністерство охорони здоров'я та Федеральна рада відповідають за розроблення законів, проєктів, програм і адміністративних заходів, на основі чого і відбувається надання медичних послуг. Реалізація всіх федеральних постанов передана в юрисдикцію виконавчим органам окремих земель. Основною установою на федеральному рівні, якій підпорядковані органи наукової експертизи, є Міністерство охорони здоров'я.

Система обов'язкового медичного страхування у Німеччині започаткована реформаторською діяльністю О. фон Бісмарка у другій половині XIX ст. [3, c. 156-157]. Нині медичним страхуванням охоплено більш ніж 90 \% населення. Працівники, що мають річний дохід нижче певного встановленого рівня, повинні обов'язково бути учасниками системи. Ті, чий дохід перевищує встановлений законодавством поріг, самостійно вирішують, чи входити до системи обов'язкового страхування або застрахуватись в одній із приватних страхових компаній. Безробітні страхуються в 
обов'язковому порядку за державні кошти. У Німеччині функціонують загальні місцеві лікарняні страхові фонди (Allgemeine Ortskrankenkassen), страхові фронди приватних компаній (Betriebskrankenkassen) та спеціальні фонди для окремих професійних груп населення (моряків, фермерів, шахтарів та ін.).

У Німеччині тарифи на послуги визначають у процесі переговорів між учасниками системи надання цих послуг. Приватні й державні лікарні, що входять до схем надання й оплати медичних послуг, визначених суб'єктами федерації, фрінансуються подвійним чином: стратегічні витрати (наприклад, довготермінове лікування) покриває уряд землі, а оперативні витрати лікарняні страхові фонди. Оперативні витрати в межах обов'язкового медичного страхування фрінансують на основі комплексних розрахунків, які включають оплату за окремі випадки захворювань (клініко-статистичні групи), оплату за процедури та добові витрати відділення. Лікарняні послуги для приватно застрахованих покривають відповідно до окремих тарифів.

Амбулаторна допомога фрінансується методом оплати окремих послуг, тарифи на які в балах установлюють під час складного процесу переговорів між представниками лікарняних страхових фрондів та асоціаціями лікарів. Пацієнти безпосередньо не платять за амбулаторну допомогу. Існує федеральний тарифний план вартості надання медичних послуг. Фактична ж грошова вартість послуг визначається на регіональному рівні і залежить від загальної кількості набраних лікарями балів [1, с. 145].

Німеччині притаманна політика державного регулювання цін на ліки. Вартість більшості препаратів відшкодовується на основі системи реферативних цін. Лікар має право виписати хворому дорожчий продукт, але пацієнт має заплатити різницю між фактичною ціною ліків і реферативною ціною. Незважаючи на поступове зростання цін, рівень витрачених коштів на ліки з кишені пацієнтів $€$ одним із найнижчих у $€ C[1$, с. 146].

Ще 2015 р. у ФРН упроваджено електронну картку здоров'я, яка містить персональні дані (фото, прізвище, ім'я, родинні звя'зки), особливості стану здоров'я пацієнта й інформацію про страховку. Картка використовується лікарями в екстремальних ситуаціях, тому до неї рекомендовано вносити дані про можливі алергії, хронічні захворювання, групу крові, зараження інфекційними захворюваннями, що сприяє значній економії часу під час надання екстреної медичної допомоги [12].

Оновленням чинного законодавства федеральна влада прагне покращити ситуацію з ключовими суспільними проблемами у сфері охорони здоров'я - боротьба з різними шкідливими звичками чи забезпечення прав пацієнтів. 32015 р. діє Закон про зміцнення здоров'я і пропаганду здорового способу життя, який спрямований на консолідацію зусиль соціально орієнтованих установ і муніципалітетів у сфері профрілактики та зміцнення здоров'я. Закон передбачає профілактику та пропаганду здорового способу життя в усіх сорерах: у кожній родині, на роботі та під час навчання. Окрім того, він направлений на усунення прогалин вакцинації у всіх вікових групах [20]. Ще раніше, 2013 р. прийнято і повністю узгоджено із цивільним і страховим законодавством Закон про права й обов'язки пацієнтів, який має забезпечити прозорість у відносинах пацієнта із системою охорони здоров'я. Контроль за якістю надання медичних послуг, їхньою ефективністю та прозорістю фінансування згідно із законом здійснює Інститут якості й ефективності в охороні здоров'я [17]. Окрім того, виконуючи положення Директиви 2014/40/€С щодо посилення контролю за тютюном федеральний уряд ініціював ще один закон, який зобов'язав виробників тютюнової продукції розміщувати на упаковках графічні попередження про шкоду паління та ввів заборону сигарет з ароматизаторами.

Важливим питанням для німецької політики у сфері охорони здоров'я $є$ поліпшення моделі догляду й піклування. Бундестаг схвалив урядовий законопроєкт із реформування служби медичної сестри. Відтак догляд за людьми похилого віку, немовлятами, пацієнтами, що потребують реабілітації, тяжкохворими здійснює спеціально навчений персонал. Закон дає можливість підвищити роль медсестринської роботи, якість і професіоналізм самого догляду [13]

Державна політика у сфері охорони здоров'я Франції. На думку багатьох дослідників французька державна система охорони здоров'я $€$ однією з найефективніших [5], а за результатами більшості порівняльних досліджень французька система охорони здоров'я отримує вищий або один із вищих балів, впевнено посідаючи перше місце рейтингу ВООЗ. По-перше, це пояснюється гібридним характером фрінансування цієї системи, що дає змогу уникнути багатьох серйозних проблем. По-друге, фрранцузька система обов'язкового медичного страхування громадян дає можливість лікуватися за невисоку ціну, компенсує більшу частину витрат на медикаменти, покриває рахунки за перебування у лікарнях і медсестринський догляд за пацієнтами вдома. По-третє, Франція має численні та якісні лікарні, висококваліфікованих лікарів та доступне кожному медичне обслуговування.

Основні засади французької політики у сфері охорони здоров'я апробовували багато десятків років. Фінансується система охорони здоров'я у Франції за рахунок відрахувань від прибутків кожного працевлаштованого громадянина $(0,75 \%$ окладу), внесків підприємств (12,8 \% окладу працівника) та державної казни (надходження від акцизних зборів на алкогольні напої і тютюнові вироби). Оплата за обслуговування проводиться через страхові фонди. У кожного працюючого жителя країни відраховують певний відсоток із заробітної плати, щоб у майбутньому можна було заплатити за медичне обслуговування й отримати кошти на закупівлю ліків. Навіть уже отримуючи пенсію, французи продовжують сплачувати внески до страхових компаній.

У Франції базовий рівень загального обов'язкового медичного страхування забезпечують через систему страхових фондів. Формально ці фонди є приватними компаніями, але насправді вони жорстко регулюються і контролюються державою. Державні службовці та робітники з трудовими договорами і контрактами страхуються всі без винятку. Найбільшим страховим фондом $€$ "Загальна національна система медичного страхування", що забезпечує страховками до 83 \% населення країни, тобто більшість працівників країни. Окремі страхові схеми охоплюють робітників із ссрери сільського господарства, осіб, які займаються індивідуальною трудовою діяльністю, і представників деяких "особливих" професій: шахтарів, транспортних робітників, діячів мистецтва, священників і державних нотаріусів. Ті, хто не працює або має вільну професію, мають право на соціальне страхування, якщо їхній річний прибуток не перевищує встановленого законом максимуму. Для них існує окремий спеціалізований страховий фонд. Великі загальнонаціональні страхові структури поділяють на фонди меншого масштабу за регіональним принципом. У цілому загальнонаціональна система медичного страхування охоплює близько 99 \% громадян Франції.

Теоретично всі ці цільові надходження мають забезпечувати фінансування системи соціального стра- 
хування в повному обсязі й компенсувати всі витрати в межах програми державного медичного страхування. Однак, як показує практика, завжди спостерігається десіцит коштів.

Заклади охорони здоров'я у Франції поділяються на державні та приватні. Приватні лікарні $€$ комерційні та некомерційні. Розвинена система медичного страхування дозволяє всім громадянам однаковою мірою звернутися до будь-якого типу медичного закладу, які між собою відрізняються спектром надання медичних послуг [7]. У разі хвороби француз має право звернутися до будь-якого лікаря. Однак у випадку звернення до приватної установи страхова компанія оплатить лише трохи більше 80 \% вартості медичних послуг і компенсує $80 \%$ коштів по рахунках за ліки й госпіталізацію [1, c. 140]. У результаті приблизно 15-20 \% обсягу медичних послуг французи оплачують із власної кишені.

У структурі правової системи Франції закони, що регулюють правовідносини у сфері охорони здоров'я, зведено в Кодекс законів про громадське здоров'я "Code de lasante publique". Кодифікація була здійснена відповідно до Постанови уряду від 5.10.1953 р. У цьому кодексі зібрано закони й підзаконні нормативні акти, зазначено їхні першоджерела, дати прийняття та внесення поправок. Крім того, до кожної статті закону додаються підзаконні нормативні акти, що конкретизують юридичний механізм їхньої реалізації. Кодекс складається з 9 частин. Такий приклад кодифікації й уніфікації правових норм у сфері охорони здоров'я $€$ досить показовим. Звичайно, в цьому кодексі є і прогалини, наприклад, недостатнє відображення економічних механізмів функціонування закладів охорони здоров'я. Однак у цілому можна відзначити раціональність такого підходу.

Окремим напрямком державної політики у сфері охорони здоров'я у Франції $€$ багатогранний підхід до профрілактики захворюваності та збереження здоров'я. у Франції за всебічної державної підтримки реалізувалися і продовжують реалізовуватися національні та загальноєвропейські програми: до 2017 р. виконувалася Програма з профілактики вживання наркотичних речовин [18]; до 2019 р. - Національна програма проти куріння, що виконується за трьома напрямами (антиреклама тютюнових виробів, заходи щодо допомоги курцям припинити палити, тиск економічними методами на продаж тютюну) [21]; "Європейський План дій щодо скорочення шкідливого вживання алкоголю на 20122020 роки" [19] та ін. Також можна згадати і Закон про адаптацію до старіння, прийнятий у 2015 р. у Франції, який сприяє вирівнюванню умов, в яких перебувають люди похилого віку, та покращенню якості їхнього життя, особливо тих, які потребують сторонньої допомоги [15]. Значну увагу приділяють охороні праці, психосоціальним ризикам на роботі, психічному здоров'ю і психіатрії, профрілактиці суїцидів. Також здійснюють заходи, спрямовані на здорове харчування і фрізичну активність, сексуальне здоров'я [16].

У Франції дебатують щодо надмірних витрат і зростання дефіциту бюджету охорони здоров'я. 2018 р. було розпочато реформу охорони здоров'я, направлену на підвищення оплати праці медичних працівників і пошук джерел фінансування для цієї цілі. Однак уже в травні 2020 р. президент Е. Макрон у розпал пандемії COVID-19 визнав "помилку" у стратегії реформи охорони здоров'я та підтвердив підготовку плану масштабних інвестицій у систему французьких лікарень.

Незважаючи на постійно зростаючий дефіцит у бюджеті охорони здоров'я, система приносить чималі дивіденди. Наприклад, велика кількість літніх людей $€$ цілком працездатними після лікування, а це означає, що вони вигідні державі. У країні середня тривалість життя громадян сягає 81 року. Альтернативні способи медичного обслуговування, скажімо, лікування без госпіталізації, також стають дедалі поширенішими. Хоча державні лікарні, приватні клініки та благодійні медичні центри загалом задовольняють усі потреби пацієнтів.

Національні системи охорони здоров'я в різних країнах не варто ідеалізувати. Кожна з них має багато позитивних рис і водночас - значні вади. Постійне зростання витрат на фінансування охорони здоров'я та вартості лікування, недостатній рівень оплати праці медичного персоналу, неоднаковий доступ усіх категорій населення до медичних послуг, черги на лікування (у бюджетній моделі особливо відчутні) породжує необхідність подальшого вдосконалення і реформування вже існуючих моделей. Окремий аспект реформування пов'язаний із пандемією COVID-19, яка оголила багато проблем навіть у найефективніших системах охорони здоров'я і після подолання якої з великою долею ймовірності більшість країн суттєво видозмінять державну політику у ссрері охорони здоров'я.

ВИСНОВКИ. Державна політика у сфері охорони здоров'я унікальна для кожної країни, на формування якої вплинули історичне минуле, політичний режим, національний менталітет та інші фактори. Принципи організації державної політики у сфері охорони здоров'я достатньо варіюються, однак чи не єдиної спільною їхньою рисою $€$ незадоволення населення системою охорони здоров'я власної країни, що призводить до постійного пошуку шляхів удосконалення, поліпшення чи реформування цієї сфери. Ця тенденція характерна як для європейських країн із достатньо якісною й ефективною системою охорони здоров'я, так і в Україні, яка лише шукає свою унікальну модель. В умовах реформування системи охорони здоров'я та вироблення нових підходів до державної політики в цій сфері варто скористатися хоча б частиною того позитивного досвіду, що вже накопичений країнами Західної Європи.

Певні позитивні зрушення вже зроблено, наприклад, забезпечено вільний вибір пацієнтом лікаря (у первинній ланці), що сприяє конкуренції і поліпшенню якості медичної допомоги. Однак вважаємо, що одним із подальших напрямів реформування системи охорони здоров'я України перш за все має стати запровадження обов'язкового державного медичного страхування, що сприятиме виходу галузі із системної кризи. А $з$ огляду на соціально-економічні особливості розвитку нашої країни, вважаємо, що страхування має здійснюватися на тристоронній основі: відрахування від доходів підприємців, відрахування з державного бюджету та страхові внески населення.

Під будь-які реформи держава повинна підвести і відповідну нормативно-правову базу. Тут прикладом може стати Франція, де існує спеціальний Кодекс законів про громадське здоров'я. Створення в Україні в ході реформи подібного кодифікованого акта у сфері охорони здоров'я допоможе швидко очистити законодавство від застарілих норм і сприятиме якісному правовому регулюванню відносин між пацієнтами, закладами охорони здоров'я, страховими компанія та державою.

Державна політика у сфері охорони здоров'я в Україні переважно сконцентрована на лікуванні різних недуг, тоді як у розвинутих країнах дедалі яскравіше відчуваємо спроби урядів і громадських організацій превентивними заходами зменшити захворюваність i підвищити загальний рівень здоров'я нації. Тому вважаємо, що заходам, які спрямовані на попередження та профрілактику виникнення хвороб, чиновникам варто приділити значно більше уваги.

Перспективною темою подальших досліджень у цьому напрямі може стати вивчення питань впливу пандемії COVID-19 на систему охорони здоров'я і на державну політику в цій галузі. 
Список використаних джерел

1. Воробйов В. В. Досвід провідних країн світу в управлінні сферою охорони здоров'я / В. В. Воробйов // Форум права. - 2011. - № 2. C. $139-146$.

2. Долот В. Д. Система охорони здоров'я в Україні: вибір національної моделі розвитку / В. Д. Долот // Державне управління: удосконалення та розвиток. - 2013. - № 2. URL: http://nbuv.gov.ua/ UJRN/Duur 2013 2 11 (дата звернення: 05.11.2020).

3. Крижевський А. В. Становлення та розвиток міжнародних стандартів щодо правового регулювання праці / А. В. Крижевський, О. О. Дерій // Часопис Київського університету права. - 2019. - № 3. C. $154-161$.

4. Матвієнко Ю. Порівняльний аналіз систем охорони здоров'я малих країн Європи / Ю. Матвієнко // Медицина світу. - 2014. T. XXXVI. - № 2. URL: http://msvitu.com/archive/2014/february/article-10.php

5. Матвієнко Ю. Французька і британська моделі охорони здоров'я (огляд) / / Ю. Матвієнко // Медицина світу. - 2014. - Т. XXXVI. № 5. URL: http://msvitu.com/archive/2014/may/article-9.php

6. Москаленко В. Ф. Тенденції громадського здоров'я населення Швеції та особливості організації системи охорони здоров'я / В. Ф. Москаленко // Internal medicine. - 2007. - № 5(5). URL: http://www.mif-ua.com/archive/article/3052 (дата звернення: 05.11.2020).

7. Приходько Т. Медична реформа: уроки французької ситеми охорони здоров'я / Т. Приходько // Медична газета України. URL: https://pharma.net.ua/publications/articles/14415-medichna-reforma-yrokifrancyzkoyi-sistemi-ohoroni-zdorovia (дата звернення: 05.11.2020).

8. Системы здравоохранения: время перемен. Швеция (ресерат обзора) - Копенгаген, 2002 - 10 с.

9. Співак М. В. Державна політика здоров'язбереження: світовий досвід і Україна / М. В. Співак. - К. : Ін-т держави і права ім. В. М. Корецького НАН України, 2016. - 535 с.

10. Anell A. Sweden: Health system review / A. Anell, A Glenngard, S. Merkur // Health Systems in Transition. - 2012. - 14(5). - 159 p.

11. Continuity and long - term thinking in ANDT work. URL: http://www.government.se/government-policy/public-health (accessed: 06.03.2016).

12. Die elektronische Gesundheitskarte. URL: http://www.bmg.bund.de/ themen/krankenversicherung/e-health-initiative-und-telemedizin/allgemeineinformationen-egk.html (accessed: 06.10.2020).

13. Gesetzentwurf zur Reform der Pflegeberufe. URL: http://www.bmg.bund.de/ministerium/meldungen/2016/pflegeberufsgesetz1-lesung-bt.html (accessed: 11.09.2020).

14. Kaati P. Sweden's Health Care System / P. Kaati // Handbook of International Health Care Systems. - New York, 2002. - P. 291-328.

15. Loi relative a l'adaptation de la societe au vieillissement. URL: http://www.pour-les-personnes-agees.gouv.fr/actualites/la-loi-relativeladaptationde-la-societe-au-vieillissement (accessed: 14.10.2020).

16. Ministere des Affaires sociales et de la Sante // URLla Sante. URL: http://social-sante.gouv.fr/ (accessed: 26.08.2020).

17. Patientenrechte. Bundesministerium für Gesundheit. URL: https://www.bmg.bund.de/ (accessed: 18.10.2020).

18. Plan Nacional de Inversiones 2014-2018. URL: http://web.minsal.cl/ sites/default/files/INVERSIONES.pdf (accessed: 12.09.2020).

19. Politique de sante publique en matiere de consommation d'alcool. URL: http://social-sante.gouv.fr/prevention-en-sante/addictions/article/politiquede-sante-publique-en-matiere-de-consommation-d-alcool (accessed: 27.10.2020)

20. Praventions gesetz. URL: http://www.bmg.bund.de/themen/ praevention/praeventionsgesetz.html (accessed: 30.09.2020).

21. Programme National de reduction du tabagisme 2014-2019. URL: https://www.ligue-cancer.net/article/35091_programme-national-dereductiondu-tabagisme (accessed: 09.10.2020)

22. Social care. Ministry of Health and Social Affairs. Sweden. URL: http://www.government.se/government-of-sweden/ministry-of-health-andsocialaffairs/\&prev= (accessed: 23.08.2020).

\section{References}

1. Vorobiov, V. (2011). Dosvid providnykh krain svitu v upravlinni sferoiu okhorony zdorov'ia [The Experience in Leading Countries in the Management of Health Sector]. Forum prava, 2, 139-146 (in Ukrainian)

2. Dolot, V. (2013) Systema okhorony zdorov'ia v Ukraini: vybir natsionalnoi modeli rozvytku [Healthcare system in Ukraine: choosing a national development model]. Public administration, improvement and de- velopment, 2. URL:http://nbuv.gov.ua/UJRN/Duur_2013_2_11 (Last accessed: 05.11.2020) (in Ukrainian)

3. Kryzhevskyi, A.\&Derii, O. (2019) Stanovlennia ta rozvytok mizhnarodnykh standartiv shchodo pravovoho rehuliuvannia pratsi [Establishment and development of international standards of legal regulation of labor]. Law Review of Kyiv University of law, 3, 154-161 (in Ukrainian)

4. Matviienko, Yu. (2014). Porivnialnyi analiz system okhorony zdorovia malykh krain Yevropy [Comparative analysis of health care systems in small European countries]. World medicine, XXXVI, 5. Retrieved from: http://msvitu.com/archive/2014/may/article-9.php. (in Ukrainian)

5. Matviienko, Yu. (2014). Frantsuzka i brytanska modeli okhorony zdorovia (ohliad) [French and British models of health care (review)]. World medicine, XXXVI, 5 Retrieved from: http://msvitu.com/archive/2014/may/ article-9.php. (in Ukrainian)

6. Moskalenko, V. (2007). Tendentsii hromadskoho zdorov'ia naselennia Shvetsii ta osoblyvosti orhanizatsii systemy okhorony zdorov'ia [Swedish public health trends and features of the health care system]. Internal medicine, 5(5). Retrieved from: http://www.mif-ua.com/archive/article/3052. (in Ukrainian)

7. Prykhodko, T. (2015). Medychna reforma: uroky frantsuzkoi sytemy okhorony zdorov'ia [Medical reform: lessons of the French health care system] Medical newspaper of Ukraine. Retrieved from: https://pharma.net.ua/ publications/articles/14415-medichna-reforma-yroki-francyzkoyi-sistemiohoroni-zdorovia (in Ukrainian)

8. Sistemy zdravookhraneniya: vremya peremen. Shvetsiya (referat obzora) [Health systems: a time of change. Sweden], (2002). Copenhagen (in Russian)

9. Spivak, M. (2016). Derzhavna polityka zdoroviazberezhennia: svitovyi dosvid i Ukraina [State health policy: world experience and Ukraine.]. Kyiv (in Ukrainian)

10. Anell, A., Glenngard, A.,\&Merku, S. (2012) Sweden: Health system review. Health Systems in Transition, 14(5), 159.

11. Continuity and long - term thinking in ANDT work. URL: http://www.government.se/government-policy/public-health (Last accessed: 06.03.2016).

12. Die elektronische Gesundheitskarte. URL: http://www.bmg.bund.de/ themen/krankenversicherung/e-health-initiative-und-telemedizin/allgemeineinformationen-egk.html (Last accessed: 06.10.2020).

13. Gesetzentwurf zur Reform der Pflegeberufe. URL: http://www.bmg.bund.de/ministerium/meldungen/2016/pflegeberufsgesetz1-lesung-bt.html (Last accessed: 11.09.2020).

14. Kaati P. (2002). Sweden's Health Care System. Handbook of International Health Care Systems. New York, 291-328.

15. Loi relative a l'adaptation de la societe au vieillissement. URL: http://www.pour-les-personnes-agees.gouv.fr/actualites/la-loi-relativeladaptationde-la-societe-au-vieillissement (Last accessed: 14.10.2020)

16. Ministere des Affaires sociales et de la Sante // URLla Sante. URL: http://social-sante.gouv.fr/ (Last accessed: 26.08.2020).

17. Patientenrechte. Bundesministerium für Gesundheit. URL: https://www.bmg.bund.de/ (Last accessed: 18.10.2020).

18. Plan Nacional de Inversiones 2014-2018. URL: http://web.minsal.cl/ sites/default/files/INVERSIONES.pdf (Last accessed: 12.09.2020).

19. Politique de sante publique en matiere de consommation d'alcool. URL:http://social-sante.gouv.fr/prevention-en-sante/addictions/article/ politique-de-sante-publique-en-matiere-de-consommation-d-alcool (Last accessed: 27.10 .2020$)$.

20. Praventions gesetz. URL: http://www.bmg.bund.de/themen/ praevention/praeventionsgesetz.html (Last accessed: 30.09.2020)

21. Programme National de reduction du tabagisme 2014-2019. URL: https://www.ligue-cancer.net/article/35091_programme-national-dereductiondu-tabagisme (Last accessed: 09.10.2020)

22. Social care. Ministry of Health and Social Affairs. Sweden. http://www.government.se/government-of-sweden/ministry-of-health-and socialaffairs $/ \&$ prev $=$ (Last accessed: 23.08 .2020$)$.

Наукове дослідження проведено в межах держбюджетної теми № 19БФ042-01M "Соціально-правові засади збереження та розвитку трудового потенціалу України"

Received: $12 / 10 / 2020$

Accepted: $09 / 11 / 2020$

A. Kryzhevskyi, PhD (History), Assist.

O. Kryzhevska, PhD (Law), Assist.

Taras Shevchenko National University of Kyiv, Kyiv, Ukraine

PUBLIC POLICY IN THE SPHERE OF HEALTH PROTECTION IN LEADING COUNTRIES OF EUROPE: LEGAL ASPECT

The article examines the state policy in the field of health care in the leading European countries: Sweden, Germany and France. The purpose of this article is to analyze and systematize the basic organizational and legal foundations of state health policy in the EU and to develop recommendations for improving and reforming the Ukrainian health care system. The research was carried out in terms of the principles of historicism, objectivity, versatility, complementarity and validity, which created a reliable methodological basis for a comprehensive analysis of the subject. The work used comparative law, formal law, system-structural, classification method, modelling method, specific statistics, historical law and other methods of scientific analysis in accordance with the subject of research.

The paper argues that public health policy is unique in each country, and its formation has been influenced by the historical past, political regime, national mentality and other factors. The article emphasizes the need to create a special code of laws in this area in Ukraine during the reform of the health care system, which will contribute to the quality of legal regulation of relations between patients, health care facilities, insurance com- 
panies and the state. The authors believe that one of the further directions of reforming the health care system of Ukraine should first of all be the introduction of compulsory state health insurance. It is substantiated that insurance should be carried out on a tripartite basis: deductions from the income of entrepreneurs, deductions from the state budget and insurance premiums. The need to strengthen measures aimed at preventing the occurrence of the disease has been proved.

Key words: health care, state policy, regulatory support, health insurance, foreign experience, reform, code, insurance premiums.

Bulletin of Taras Shevchenko National University of Kyiv. Legal Studies, 2020; 3 (114): 35-40

УДК: 347.7

DOI: https:doi.org/10.17721/1728-2195/2020/5.115-8
ISSN 1728-2195

(C) Taras Shevchenko National University of Kyiv

Publishing center "Kyiv University", 2020

Е. Кулага, канд. юрид. наук, доц. ORCID ID: 0000-0002-6405-3510,

O. Мельниченко, студ., держ. експерт Секретаріату КМУ

ORCID ID: 0000-0003-4616-1400

Київський національний університет імені Вадима Гетьмана, Київ, Україна

\section{ПРОБЛЕМИ ПРАВОВОГО СТАТУСУ НАГЛЯДОВОЇ РАДИ ДЕРЖАВНОГО АКЦІОНЕРНОГО ТОВАРИСТВА}

Здійснено огляд практичних аспектів регулювання діяльності наглядових рад акціонерних товариств в Україні, зокрема особливостей їхньої роботи на об'єктах державної власності. Шляхом аналізу положень нормативноправових актів у сфері корпоративного права досліджено останні зміни у правовому статусі наглядових рад акціонерних товариств, а також здійснено порівняння їхнього застосування до державних акціонерних товариств. Крім того, зазначені зміни порівнюються з положеннями міжнародних стандартів у сфері корпоративного управління підприємствами державної форми власності, зокрема стандартами Організації економічного співробітництва та розвитку (ОЕСР). Розглянуто поняття "наглядова рада", "державне підприємство", "фідуціарні обов'язки", а також питання прозорості та доброчесності роботи наглядових рад. Наведено актуальну практику діяльності наглядових рад державних акціонерних товариств та показано, яким чином реалізовувались їхні повноваження.

За результатами дослідження встановлено, що чинне нормативно-правове регулювання є досить складним, неузгодженим і містить внутрішні суперечності, які, з одного боку, створюють ризики для ефективної реалізації наглядовими радами своїх повноважень, а з іншого, ризики зловживань із боку наглядових рад. Автори дійшли висновку про необхідність удосконалення правової бази, яка регламентує роботу наглядових рад державних акціонерних товариств, узагальнення й уніфікації практики з різних питань компетенції наглядових рад, а також необхідності передбачення певних критеріїв відповідності членів наглядових рад вимогам щодо професійного досвіду в тій чи іншій сфері та щодо прозорості в питанні відсутності конфлікту інтересів.

Ключові слова: корпоративне управління, ОЕСР, Керівні принципи ОЕСР щодо корпоративного управління на підприємствах державної форми власності, державні підприємства, реформа, призначення, фідуціарні обов'язки, відповідальність, ключові показники ефективності.

ВСтУП. Державна власність в Україні завжди розглядалась як один із значних, якщо не визначальних, факторів економічного життя. Це підтверджується і цифррами, згідно з якими питома вага державного сектора в економіці України за 2019 р. становила 8,3 \% [14].

Реформи, що започатковані в Україні з 2014 р. та підтримуються міжнародною спільнотою, не обійшли стороною і сферу управління державною власністю та призвели до значних змін у правовому регулюванні, особливо щодо питань корпоративного управління. Протягом цього часу відбулося багато змін, але однією 3 найрезонансніших стало створення наглядових рад на державних підприємствах. У першу чергу це стосується тих, які корпоратизовані та діють у формі акціонерних товариств. У зв'язку із цим ми вважаємо за доцільне оцінити поточний стан правового регулювання діяльності наглядових рад акціонерних товариств і запропонувати можливі кроки щодо подальшого вдосконалення правового регулювання їхньої діяльності на об'єктах державної власності.

Проаналізуємо питання опрацьованості теми. Зазначимо, що проблемам правового статусу органів управління акціонерних товариств приділяється багато уваги, оскільки в Україні сфера корпоративного права проходить зараз через швидкі зміни. Ці питання досліджувались такими науковцями: Г. Попадинець, І. М. Кучеренко, Р. А. Майданик, О. М. Вінник та ін.

Для вказаної роботи також важливим $є$ питання управління об'єктами державної власності, якому в українській правовій науці також приділено багато уваги. Так, в останні роки це питання досліджувалося з погля- ду цивільного права у працях І. В. Спасибо-Фатєєвої та Ю. М. Дзери, у межах адміністративного права В. Л. Пількевич, О. О. Кравчук, господарського права О. А. Беляневич, О. П. Віхрова, Р. А. Джабраілова, О. П. Подцерковного, І. А. Селіванова, В. А. Устименко, О. Голіної, А. І. Денисова, Я. Дубової й ін. Однак єдиної позиції щодо управління об'єктами державної власності в науці господарського права немає.

Завданням цієї роботи $є$ аналіз поточного стану регулювання діяльності наглядових рад акціонерних товариств в Україні, зокрема особливостей їхньої роботи на об'єктах державної власності, та вироблення можливих пропозицій щодо вдосконалення правової бази, яка унормовує роботу наглядових рад державних підприємств. Крім того, виконано порівняння чинних норм законодавства щодо корпоративного управління з міжнародними стандартами у вказаній сфрері.

ВИКЛАД ОСНОВНОГО МАТЕРІАЛУ. Правила існування та діяльності акціонерних товариств закріплено в законодавчих актах, серед яких Господарський кодекс України, Цивільний кодекс України та Закон України "Про акціонерні товариства". Крім цих актів $€$ ще багато інших законів і підзаконних актів, що уточнюють і доповнюють їхні положення залежно від умов, у яких здійснює свою діяльність акціонерне товариство.

Цивільний кодекс визначає, що акціонерне товариство $€$ формою підприємницького товариства і, як і інші юридичні особи, таке товариство утворюється на основі установчого документа, яким $є$ статут (ч. 2 ст. 87) [13]. Кодекс поміж іншим визначає серед вимог до змісту статуту таку: він має містити відомості про органи това- 